\title{
ОЦІНКА ПОКАЗНИКІВ ЯКОСТІ ЖИТТЯ У ХВОРИХ НА ВЕРТЕБРОГЕННІ БОЛЬОВІ СИНДРОМИ ПОПЕРЕКОВО-КРИЖОВОГО РІВНЯ ТА ЇХ ЗАЛЕЖНІСТЬ ВІД СТУПЕНЯ ВИРАЖЕННЯ НЕВРОЛОГІЧНИХ РОЗЛАДІВ
}

\author{
Запорізький державний медичний університет, м. Запоріжжя, Україна
}

\begin{abstract}
Мета: виявити взаємозв'язок між ступенем вираження клініко-неврологічних розладів та показниками якості життя у хворих на вертеброгенні больові синдроми попереково-крижового рівня (ВБС ПКР).

Матеріали і методи. Обстежено 30 хворих на ВБС ПКР. У першу групу увійшли 15 пацієнтів з рефрлекторними вертеброгенними больовими синдромами (РВБС), а другу групу склали 15 хворих із дискогенними корінцевими синдромами (ДКС). Використано загальне клініко- та вертеброневрологічне дослідження, мануально-м'язове тестування, а також клінічні шкали та опитувальники для оцінки якості життя хворих.

Результати. Показники за наступними шкалами та опитувальниками були гірші у хворих 3 ДКС ПКР, аніж у пацієнтів з РВБС цього рівня: РаinDETECT - $55(50 ; 68)$ та 45 (42; 52), відповідно, р<0,001; 5-бальна шкала вертеброневрологічного десріциту (5-БШВНД) - $8(8 ; 10)$ та $5(4 ; 7)$, відповідно, р<0,001; індекс м'язового синдрому - 10 (9; 13) та 8 (6; 8), відповідно, р<0,013; візуальна аналогова шкала (ВАШ) - 3 (2; 3$)$ та 2 (2; 3), відповідно, р<0,029; Освестрі 2.1 - 15 (14; 17) та 10 (9; 14), відповідно, р<0,002; шкала інтенсивності больових відчуттів за І. П. Антоновим - $5(5 ; 7)$ проти 3 (3; 5), відповідно, р<0,008; HADS (домен тривожності) - 8 (6; 10) та 5 (4; 7), відповідно, HADS (домен депресії) - $6(4 ; 8)$ та 3 (2; 4), відповідно, р<0,045.

Відзначено сильний позитивний кореляційний зв'язок між показниками за шкалами Освестрі 2.1 та ВАШ (r=0,709, p<0,003), а також середньої сили між показниками шкал Освестрі 2.1 та IMC ( $r=0,629, p<0,012)$.

Висновки. Клініко-неврологічні розлади та показники якості життя були гіршими у хворих із ДКС ПКР, аніж у пацієнтів з РВБС ПКР. Більш сильну кореляцію клінічних даних з показниками якості життя спостерігали у хворих із ДКС ПКР, ніж у пацієнтів з РВБС ПКР.
\end{abstract}

КЛЮчОВІ СЛОВА: вертеброгенні больові синдроми; якість життя; кореляція.

Вертеброгенні больові синдроми займають одне із перших місць щодо соціоекономічного ураження людства. Це найпоширеніші захворювання периферійної нервової системи, які призводять до величезних збитків медичних та економічних ресурсів повсюди [2, 4].

Приблизно 84 \% людства стикалися із проблемою болю у спині на тому чи іншому етапі свого життя. За статистично-економічними даними, збитки від цієї хвороби сягають 12 млрд фунтів у Великій Британії, 85,9-100 млрд доларів у США та 16,5-50,0 млрд євро у Німеччині $[3,5,6]$.

Для більшості людей больові симптоми у спині проходять протягом декількох днів. Ті пацієнти, які самостійно видужують до 4 тижнів, $є$ реконвалесцентами у гострий період. Якщо купірування симптомів не відбувається, то хвороба переходить у підгострий період, що триває від 4 до 12 тижнів. У деяких хворих біль у спині триває більше 12 тижнів, тобто переходить у хронічний стан [1].

Відповідно до вищевказаного, біль у спині може мати негативний вплив на показники якості життя у хворих.

Мета дослідження: виявити взаємозв'язок між ступенем вираження клініко-неврологічних розладів та показниками якості життя у хворих на вертеброгенні больові синдроми попереково- крижового рівня (ВБС ПКР) шляхом порівняльної оцінки клінічних даних та результатів опитування за сучасними шкалами якості життя.

Задля досягнення мети були поставлені такі завдання:

1) оцінити вираження клініко-неврологічних розладів та показники якості життя у хворих на рефлекторні та корінцеві вертеброгенні больові синдроми (РВБС та ДКС відповідно);

2) провести порівняльну оцінку вираження клініко-неврологічних розладів і показників якості життя у хворих на ВБС ПКР;

3) встановити взаємозв'язок між клінічними даними та результатами опитування хворих за шкалами якості життя.

Матеріали і методи. На базі КНП «Міська клінічна лікарня № 6» Запорізької міської ради, загального неврологічного відділення обстежено 30 хворих на ВБС ПКР. Усіх хворих поділено на 2 групи. У першу групу увійшли 15 пацієнтів з РВБС - 7 чоловіків та 8 жінок, середній вік $(49,7 \pm 9,2)$ року. Другу групу склали 15 хворих 3 ДКС - 8 чоловіків та 7 жінок, середній вік $(49,8 \pm 10,6)$ року.

У роботі використано загальне клініко- та вертеброневрологічне дослідження, мануальном'язове тестування. Для більшої об'єктивізації 
дослідження застосовано такі клінічні шкали - опитувальник PainDETECT, 5-бальна шкала вертеброневрологічного дефіциту (5-БШВНД), індекс м'язового синдрому (IMC) та шкала інтенсивності больових відчуттів за І. П. Антоновим, а також шкали задля визначення рівня якості життя хворих - Освестрі 2.1, візуальна аналогова шкала (ВАШ), госпітальна шкала тривоги та депpeciï (HADS).

За результатами тесту Шапіро - Уілка, більшість даних не відповідала закону нормального розподілу, тому були використані непараметричні методи статистичної обробки даних. Якісні номінативні, в тому числі біноміальні ознаки незалежних груп дослідження, були вирахувані за допомогою точного критерію Фішера. Кількісні ознаки були статистично обраховані за допомогою критерію Манна - Уїтні та подані у вигляді медіани та міжквартильного інтервалу. Задля визначення сили та напрямку взаємозв'язку кількісних даних дослідження був використаний метод лінійного та множинного кореляційного аналізу з вираховуванням коефіцієнтів рангової кореляції Спірмена. Достовірну відмінність усіх даних приймали за р<0,05.

Результати дослідження та їх обговорення. У результаті проведення клініко- та вертеброневрологічного дослідження і мануально-м'язового тестування знайдено достовірну відмінність показників між обома групами хворих.

Пацієнти з РВБС частіше скаржилися на періодичну наявність парестезій в ділянці нижніх кінцівок, аніж хворі з ДКС (p<0,04), натомість хворі другої групи - на слабкість у м'язах попереку та/ або ніг та обмеження об'єму рухів у нижній частині спини через больові відчуття у поперековому відділі хребта (ПВХ) ( $p<0,04)$. За частотою скарги на біль у ПВХ та/або в нозі в групах не відрізнялись $(p>0,05)$.

Проведене опитування пацієнтів обох груп за шкалами якості життя показало достовірні відмінності за опитувальниками Освестрі 2.1, шкалами PainDETECT, BAШ та HADS, де у хворих 3 корінцевими ВБС ПКР спостерігали більші показ- ники, аніж у пацієнтів з ресрлекторними больовими синдромами зазначеного рівня.

Після проведення клініко-неврологічного, вертеброневрологічного огляду та мануальном'язового тестування з використанням клінічних шкал було встановлено, що показники шкали PainDETECT були гіршими у хворих з ДКС ПКР, аніж у пацієнтів з РВБС цього рівня - 55 (50; 68) та 45 (42; 52), відповідно, р<0,001. Такі дані вказують на те, що хворі на радикулопатії ПКР мали більше нейропатичного компонента болю, аніж ноцицептивного, що було характерно для пацієнтів із РВБС. За результатами дослідження за допомогою 5-БШВНД було виявлено аналогічну відмінність показників між двома групами - у хворих другої групи були більші значення, аніж у пацієнтів першої групи - $8(8 ; 10)$ та 5 (4; 7), відповідно, $\mathrm{p}<0,001$. Рівень ІМС також відрізнявся, був більшим у хворих із ДКС, аніж у пацієнтів з РВБС $10(9 ; 13)$ та $8(6 ; 8)$, відповідно, р<0,013. За шкалою больових відчуттів (І. П. Антонова) виявлено відмінність - хворі з ДКС ПКР мали гірші показники, аніж хворі з РВБС цього рівня - $3(2 ; 3)$ та 2 (2; 3), відповідно, $р<0,029$.

Використання шкал для визначення рівня якості життя та деяких його аспектів дозволило встановити наявність відмінностей у групах дослідження. За отриманими даними шкали Освестрі 2.1 з'ясовано, що гірші показники були у хворих з ДКС ПКР, аніж у пацієнтів з РВБС цього рівня - $15(14 ; 17)$ та 10 (9; 14), відповідно, p<0,002. За шкалою ВАШ спостерігали аналогічну відмінність у групах - $5(5 ; 7)$ проти $3(3 ; 5)$, відповідно, p<0,008. За шкалою HADS виявлено відмінність між групами у доменах тривожності (HADSt) та депресії (HADSд). Для хворих з РВБС були характерні більші показники за доменом тривожності (субклінічний рівень), аніж у хворих з ДКС (8 $(6 ; 10)$ та 5 (4; 7), відповідно, p<0,049), в той час як для хворих із ДКС були властиві більші показники депресивного домену шкали HADS, аніж у хворих з рефрлекторними синдромами, які, однак, не досягли субклінічного рівня $(6(4 ; 8)$ та 3 (2; 4), відповідно, р<0,045) (рис. 1).

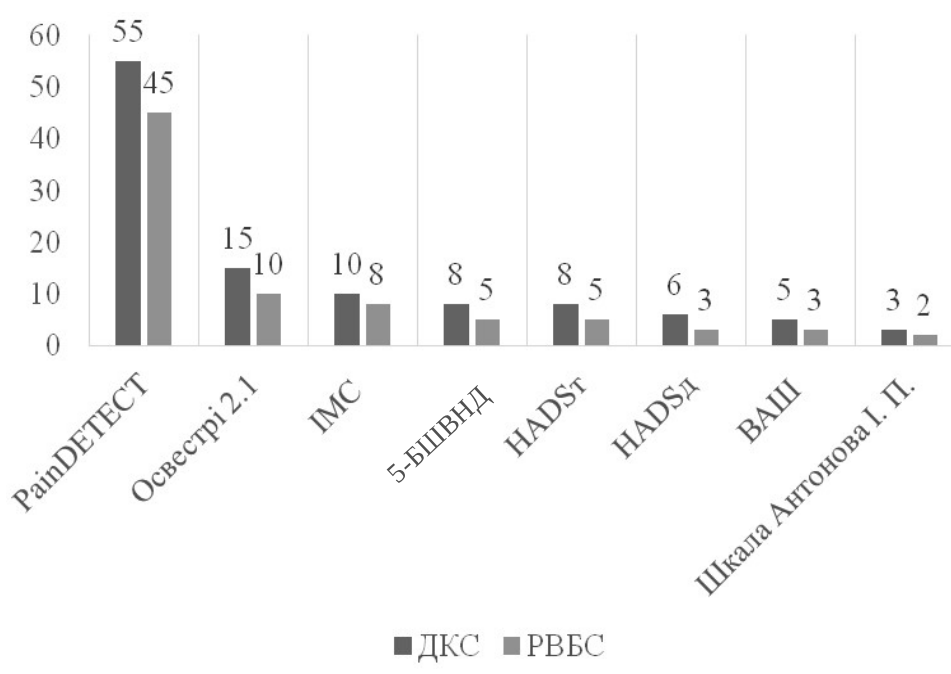

Puc. 1. Показники клініко-неврологічних даних та якості життя хворих на вертеброгенні больові синдроми попереково-крижового рівня, $р<0,05$. 
За результатами розрахунку коефіцієнтів рангової кореляції Спірмена, у хворих з ДКС відзначено сильний позитивний кореляційний зв'язок між показниками за шкалами Освестрі 2.1 та ВАШ $(r=0,709, p<0,003)$, а також середньої сили між показниками шкал Освестрі 2.1 та IMC ( $r=0,629, p<0,012)$ (рис. 2). Методом вираховування множинних коефріцієнтів кореляції відзначено взаємозв'язок між показниками шкал Освестрі 2.1, ВАШ та IMC, що мало своє відображення на графріку та описувалось таким рівнянням:

$Z=60,3+16,8 \times X-23,3 \times Y+1,2 \times X^{2}-3,4 \times X \times Y+2,4 \times Y^{2}$, де $Z$ - зміна показників за шкалою Освестрі 2.1; $X$ - зміна показників за шкалою ВАШ; Y - зміна показників за шкалою IMC.

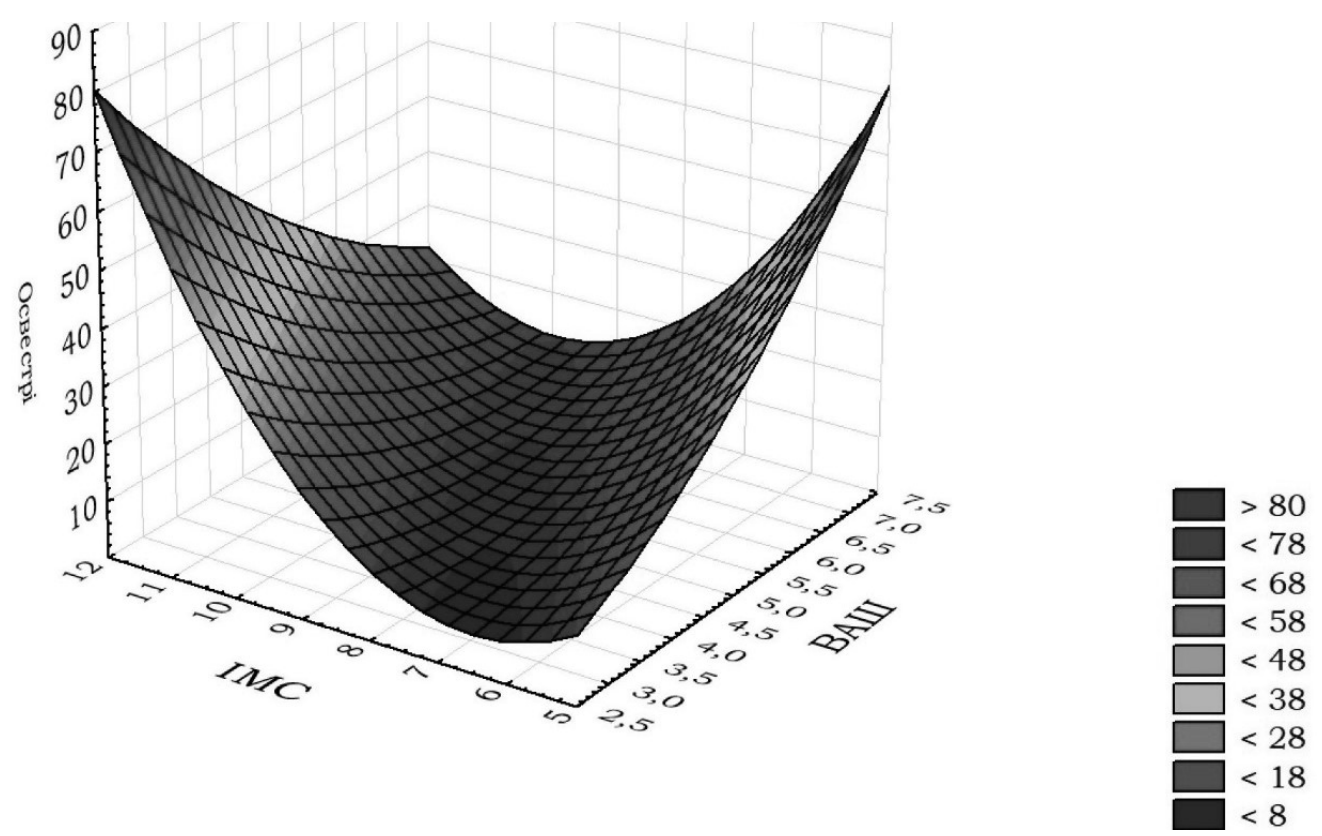

Puc. 2. Графік множинної кореляції клініко-неврологічних показників (IMC та ВАШ) і рівня якості життя хворих на дискогенні корінцеві синдроми попереково-крижового рівня за шкалою Освестрі 2.1, p<0,05.

\section{Висновки}

1. Встановлено рівень та наявність відмінності у клініко-неврологічних розладах та показниках рівня якості життя у хворих на ВБС ПКР

2. Клініко-неврологічні розлади та показники рівня якості життя були гіршими у хворих на ДКС ПКР, аніж у пацієнтів з РВБС ПКР.

3. Більш сильну кореляцію клінічних даних 3 показниками якості життя спостерігали у хворих на ДКС ПКР, ніж у пацієнтів з РВБС ПКР, що, можливо, пов'язано з більшим строком хвороби, тяжкістю перебігу та вираженням больового синдрому в хворих на радикулопатії.

Перспективи подальших досліджень полягають у дослідженні вищезазначених показників на більшій когорті пацієнтів із подальшим проведенням регресійного аналізу та встановленням причинно-наслідкових зв'язків між клініко-неврологічними даними та показниками якості життя.

\section{Список літератури}

1. Chou R. In the clinic. Low back pain / R. Chou // Ann Intern. Med. - 2014. - Vol. 160 (11). -P. 6-1.

2. Expenditures and health status among adults with back and neck problems / B. I. Martin, R. A. Deyo, S. K. Mirza [et al.] // JAMA. - 2008. - Vol. 299. - P. 656-664.

3. Juniper $M$. The epidemiology, economic burden, and pharmacological treatment of chronic low back pain in France, Germany, Italy, Spain and the UK: a literature-based review / M. Juniper, T. K. Le, D. Mladsi // Expert Opin Pharmacother. 2009. - Vol. 10. - P. 2581-2592.

4. Lost productive time and cost due to common pain conditions in the US workforce / W. F. Stewart, J. A. Ricci, E. Chee [et al.] // JAMA. - 2003. - Vol. 290. - P. 2443-2454.

5. Maniadakis N. The economic burden of back pain in the UK / N. Maniadakis, A. Gray // Pain. - 2000. - Vol. 8495. P. 103.

6. Sambamoorthi U. Multiple chronic conditions and healthcare costs among adults / U. Sambamoorthi, X. Tan, A. Deb // Expert Review of Pharmacoeconomics \& Outcomes Research. - 2015. - Vol. 15. - P. 823-832.

\section{References}

1. Chou, R. (2014). In the clinic. Low back pain. Ann Intern. Med., 160 (11), 6-1.

2. Martin, B.I., Deyo, R.A., \& Mirza, S.K. (2008). Expenditures and health status among adults with back and neck problems. JAMA, 299, 656-664. 
3. Juniper, M., Le, T.K., \& Mladsi, D. (2009). The epidemiology, economic burden, and pharmacological treatment of chronic low back pain in France, Germany, Italy, Spain and the UK: a literature-based review. Expert Opin. Pharmacother., 10, 2581-2592.

4. Stewart, W.F., Ricci, J.A., Chee, E., Morganstein, D., \& Lipton R. (2003). Lost productive time and cost due to common pain conditions in the US workforce. JAMA, 290, 2443-2454.

5. Maniadakis, N., \& Gray A. (2000). The economic burden of back pain in the UK. Pain, 8495, 103.

6. Sambamoorthi, U., Tan, X., \& Deb, A. (2015). Multiple chronic conditions and healthcare costs among adults. Expert Review of Pharmacoeconomics \& Outcomes Research, 15, 823-832.

\section{THE LIFE QUALITY RATES ASSESSMENT IN PATIENTS WITH VERTEBROGENIC PAIN SYNDROMES OF LUMBAR-SACRAL LEVEL AND ITS DEPENDENCE ON THE NEUROLOGICAL DISORDERS DEGREE}

O. A. Kozyolkin, S. O. Miedviedkova, M. P. Pukhalskyi

Zaporizhzhia State Medical University, Zhaporizhzhia, Ukraine

Purpose: to identify the relationship between the severity of neurological disorders and life quality in patients with vertebrogenic pain syndromes (VPS) of the lumbosacral level (LSL).

Materials and Methods.. Thirty patients with VPS LSL were studied. The first group included 15 patients with reflex vertebrogenic pain syndromes (RVPS). The second group consisted of 15 patients with discogenic radicular syndromes (DRS). General clinical and vertebrological neurological studies, manual and muscular testing, as well as clinical scales and quality of life questionnaires were used.

Results. The following scales and questionnaires rates were worse in patients with DRS LSL than in patients with RVPS of this level: PainDETECT - $55(50 ; 68)$ and $45(42 ; 52)$, respectively, $p<0,001 ; 5$-point scale of vertebral and neurological deficit (5-PSVND) - $8(8 ; 10)$ and $5(4 ; 7)$, respectively, $\mathrm{p}<0.001$; IMS $-10(9 ; 13)$ and 8 $(6 ; 8)$, respectively, $p<0,013$; pain intensity scale by I. P. Antonov $-3(2 ; 3)$ and $2(2 ; 3)$, respectively, $p<0,029$; Osvestri $2.1-15(14 ; 17)$ and $10(9 ; 14)$, respectively, $p<0.002$; VAS $-5(5 ; 7)$ against $3(3 ; 5)$, respectively, $p<$ 0,008 ; HADS (anxiety domain) - $8(6 ; 10)$ and $5(4 ; 7)$, respectively, HADS (depression domain) $-6(4 ; 8)$ and 3 $(2 ; 4)$, respectively, $p<0,045$.

There was a strong positive correlation between the Oswestry scale 2.1 rates and VAS $(r=0.709, p<0.003)$ were observed, as well as the medium positive correlation between the indicators on the Oswestry scale and IMS $(r=0.629, p<0.012)$.

Conclusions. Neurological disorders and life quality indicators were worse in patients with DRS LSL than in patients with RVPS LSL. There was stronger correlation between clinical data and life quality rates in patients with DRS LSL than in patients with RVPS LSL.

KEY WORDS: vertebrogenic pain syndromes; life quality; correlation.

Рукопис надійшов до редакції 07.05.2021 p.

Відомості про авторів:

Козьолкін Олександр Анатолійович - доктор медичних наук, професор, завідувач кафедри нервових хвороб Запорізького державного медичного університету; тел.: +38(061) 239-34-05.

Мєдвєдкова Світлана Олександрівна - доктор медичних наук, професор Запорізького державного медичного університету; тел.: +38(061) 239-34-05.

Пухальський Микола Павлович - лікар-інтерн, старший лаборант кафедри нервових хвороб Запорізького державного медичного університету; тел.: +38(061) 239-34-05. 